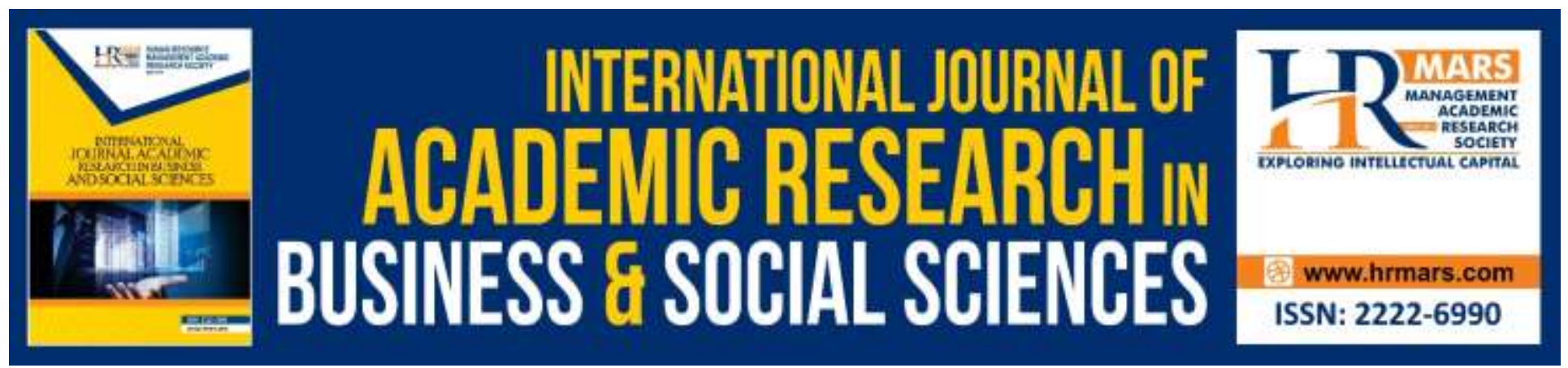

\title{
Tax Evasion: Impact of Internal and External Factors, An Individual Tax Payer Perception
}

Deden Tarmidi, Adelina Suryati, Sri Purwaningsih

To Link this Article: http://dx.doi.org/10.6007/IJARBSS/v10-i5/7240

DOI:10.6007/IJARBSS/v10-i5/7240

Received: 02 March 2020, Revised: 14 April 2020, Accepted: 20 April 2020

Published Online: 27 May 2020

In-Text Citation: (Tarmidi et al., 2020)

To Cite this Article: Tarmidi, D., Suryati, A., \& Purwaningsih, S. (2020). Tax Evasion: Impact of Internal and External Factors, An Individual Tax Payer Perception. International Journal of Academic Research in Business and Social Sciences, 10(5), 675-685.

Copyright: @ 2020 The Author(s)

Published by Human Resource Management Academic Research Society (www.hrmars.com)

This article is published under the Creative Commons Attribution (CC BY 4.0) license. Anyone may reproduce, distribute, translate and create derivative works of this article (for both commercial and non-commercial purposes), subject to full attribution to the original publication and authors. The full terms of this license may be seen

at: http://creativecommons.org/licences/by/4.0/legalcode

\section{Vol. 10, No. 5, 2020, Pg. $675-685$}

http://hrmars.com/index.php/pages/detail/IJARBSS

JOURNAL HOMEPAGE

Full Terms \& Conditions of access and use can be found at http://hrmars.com/index.php/pages/detail/publication-ethics 


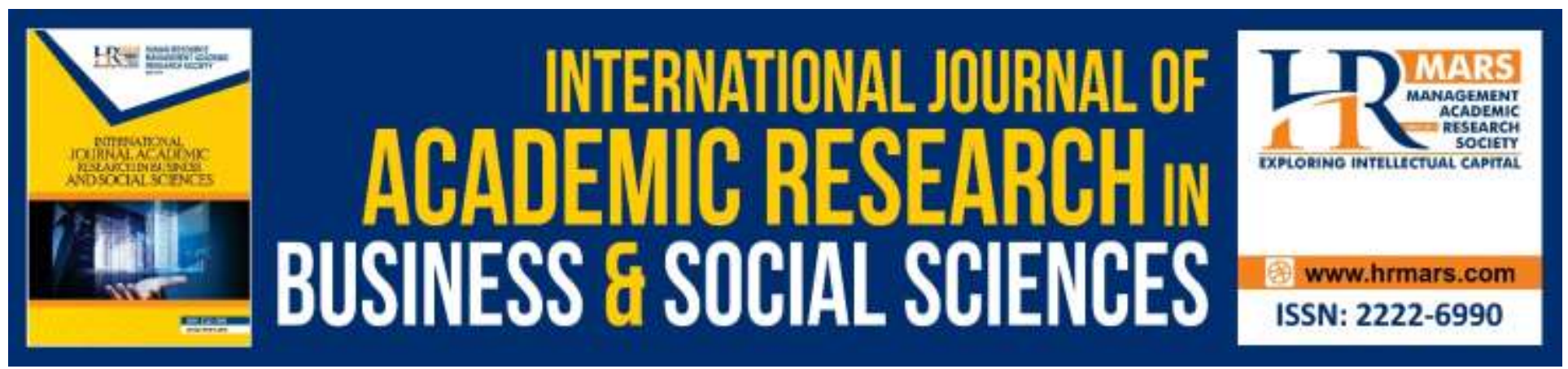

\title{
Tax Evasion: Impact of Internal and External Factors, An Individual Tax Payer Perception
}

\author{
Deden Tarmidi ${ }^{1}$, Adelina Suryati², Sri Purwaningsih ${ }^{1}$ \\ 'Universitas Mercu Buana, Jakarta, Indonesia, ${ }^{2}$ Universitas Bhayangkara Jakarta Raya, Jakarta, \\ Indonesia \\ Email: deden.tarmidi@mercubuana.ac.id
}

\begin{abstract}
This study aims to determine the perception of taxpayers on tax evasion that is influenced by internal factors and external factors of taxpayers. As the locus of control theory that a person's actions are influenced by internal factors of the person himself and external factors around the person. Tax evasion is known as a factor causing the non-achievement of state revenue from taxes so far. The MSME was used as a respondent in this study because of its large number in Indonesia and grow the country's economy.

The results found that ethics and understanding of taxation as internal factors have an influence on tax evasion, as well as tax justice as an external factor also has an influence on tax evasion. From a comparative analysis, internal factors have a stronger influence than external factors. This result can be used by the Directorate General of Taxes in minimizing tax evasion by fostering individual enthusiasm in complying with tax regulations.
\end{abstract}

Keywords: Tax Evasion, Religiosity, Ethics, Understanding Taxation, Information Technology, Tax Audit, Tax Justice.

\section{Introduction}

Tax evasion is one of the causes of a country's tax revenue not being reached, including in Indonesia. The "Panama Paper" case explains that there are still many companies in the world that avoid tax by storing assets in Tax Heaven Countries (Ihsanudin, 2016). Including the case of the issuance of fictitious tax invoices in Indonesia which cost the country a lot (Utama, 2015). Actually the Directorate General of Taxes has done various things to reduce the amount of tax evasion so that tax revenue is as targeted, but still the tax revenue target is not reached and the level of tax evasion remains high. So this study was conducted to find out what influenced tax evasion and how the government minimized it.

Many factors affect taxpayers to carry out tax evasion, internal factors of taxpayers and external factors as explained by the locus of control theory. Showa \& Utomo (2018) and Surahman \& Putra (2018) in their research found that one's religiosity has an impact on his ethics not to carry out tax evasion, even though these results were not found in Basri (2015) and Dharma et al. (2016). In 
addition to religiosity as an internal factor for taxpayers, several studies have found that ethics and understanding of taxation by individual taxpayers influence tax evasion (Dewi \& Merkusiwati, 2017; Putri et al., 2017; Dharma et al., 2016; Surahman \& Putra, 2018).

In the external factors of taxpayers, information technology (Ardyaksa \& Kriswanto, 2014; Permatasari \& Laksito, 2013; Fitriyanti, et al., 2017; Utami \& Helmi, 2016) can minimize tax evasion more taxpayers feel easy to carry out taxation rights and obligations due to good information technology, as well as the Directorate General of Taxes it is easier to supervise taxpayers so that tax evasion acts are reduced, such as tax audits that make taxpayers afraid to carry out tax evasion (Dewi \& Merkusiwati, 2017). In addition. Taxpayers' perceptions of justice in their country (Ismarita, et al., 2018; Dewi \& Merkusiwati, 2017; Tobing, et al., 2015; Paramita \& Budiasih, 2016) also have an impact on tax evasion, when people feel that the level of justice in the country is already high so people will voluntarily obey in paying taxes for the country's development. However, different results were found in other studies where justice was found to have a positive impact on tax evasion (Utami \& Helmi, 2016; Ervana, 2019; Handayani \& Cahyonowati, 2014) and other studies found that justice did not have an impact on tax evasion (Friskianti \& Handayani, 2014 ; Maghfiroh, 2016) as well as other results that found that information technology has no influence on tax evasion (Friskianti \& Handayani, 2014; Ismarita, et al., 2018; Paramita \& Budiasih, 2016).

Based on the background above and the research gap found in previous studies, this study try to reanalyzing internal factors such as Religiosity, Ethics and Understanding of Taxation and external factors of Taxpayers such as Information Technology, Tax Audit and Justice in its effect on tax evasion is based on the perception of MSMEs in the Pasar Tanah Abang. In addition to knowing what influences the taxpayer doing tax evasion, this study also wants to find out which factors between internal and external taxpayers have more influence on tax evasion, so that this research is unique in addition to the regression analysis as well as a comparative analysis of internal factors and external factors on tax evasion.

\section{Literature Review \\ Locus of Control Theory}

The concept of locus of control was first put forward by Rotter (1966), a social learning theorist. Locus of control is one of the personality variables (personility), which is defined as an individual's belief in the ability to control one's own destiny (Kreitner and Kinicki, 2005).

Robbins and Judge (2007) define locus of control as the degree to which individuals believe that they are determinants of their own destiny. Internals are individuals who believe that they are in control of whatever is happening to them, while externals are individuals who believe that whatever happens to them is controlled by outside forces such as luck and opportunity.

Based on the explanation above it can be concluded that individuals who have confidence that the fate or events in their lives are under their control, said that these individuals have an internal locus of control. While individuals who have the belief that the environment is the one who has control over the fate or events that occur in their lives is said to have an external locus of control.

In connection with the act of tax evasion, taxpayers who have an internal locus of control can control themselves with what they have such as the level of religiousity, as well as ethics and understanding of taxation. How strong the influence of external parties on taxation, taxpayers who have an internal locus of control remain strong in their own establishment so that results in decisions taken whether to do or avoid tax evasion. While taxpayers who have an external locus of control do not have 
INTERNATIONAL JOURNAL OF ACADEMIC RESEARCH IN BUSINESS AND SOCIAL SCIENCES

Vol. 10, No. 5, May, 2020, E-ISSN: 2222-6990 @ 2020 HRMARS

confidence in themselves. External factors about taxation such as information technology, tax audit and tax justice that exist in the country where he belongs have a major role in his actions in carrying out or avoiding tax evasion activities.

\section{Conceptual Framework and Hypothesis Development}

Religiosity is the level of depth of understanding one's religion. Taxpayers who have a high level of religious understanding certainly understand that obeying state rules as long as they do not conflict with religious rules is mandatory, so that evasion is wrong. But not a few religious adherents are of the opinion that tax is an arbitrary action from the government and does not exist in the teachings of religion so they prefer to leave it. In line with the research of Shova \& Utomo (2018) and Surahman \& Putra (2018) who found that the religiosity of taxpayers had an influence on tax evasion.

H1. Religiosity has an effect on tax evasion

Ethics is something that a person has in distinguishing right from wrong so that it encourages him to ecause it is against the applicable provisions, thus encouraging it to avoid tax evasion. But with the tax case so far, taxpayers also think that paying taxes will only help tax crime cases getting bigger so that tax evasion can be considered right. In line with Zirman's research (2015) which found that ethics of taxpayers has an influence on tax evasion.

H2. Ethics affect tax evasion

Taxpayers who have a good understanding of taxation rights and obligations are aware of the do's and don'ts of taxation obligations so as to help them comply with taxes (Sarpingah, et al., 2017) and avoid tax evasion because of the consequences attached to these actions. Although it cannot be denied that the more clever a person is, it will encourage him to look for loopholes to enrich themselves, one of them by means of tax evasion. In line with Dharma, et al. (2016) and Surahman \& Putra (2018) who in their research found that understanding taxation had an effect on tax evasion.

H3. Understanding taxation affects tax evasion

Taxation services in the form of information technology issued by regulators in helping taxpayers to carry out their taxation rights and obligations, on the other hand the supervision of the tax authorities can be improved and easier. With strong information technology, taxpayers do not dare to carry out tax evasion because information has been integrated thereby reducing tax evasion (Ardyaksa \& Kiswanto, 2014; Permatasari \& Laksito, 2013; Fitriyanti, et al., 2017). But the more sophisticated information technology, it could be used for ways that are not good by taxpayers such as tax evasion.

H4. Information Technology has an effect on tax evasion

By its compelling nature, taxes are a burden for all people and according to the provisions in force that the inspection process will be carried out for certain taxpayers who are suspected of carrying out tax evasion actions that could harm the country. The tax audit procedure is a frightening specter for some taxpayers so as to successfully minimize tax evasion (Dewi \& Merkusiwati, 2017).

H5. Tax audits affect tax evasion

Some taxpayers voluntarily comply with all applicable tax provisions, some are still carrying out tax evasion actions because justice is deemed inappropriate so that it creates public distrust of the 
government and ultimately does not comply with applicable regulations (Tarmidi, 2019; Utami \& Helmi, 2016; Ervana, 2019; Handayani \& Cahyonowati, 2014). Some people think that when the level of tax justice is high, taxpayers will avoid tax evasion because all are aware of the functions and benefits of taxation (Nickerson et al., 2009; Ismarita, et al., 2018; Dewi \& Merkusiwati, 2017; Tobing, et al., 2015; Paramita \& Budiasih, 2016; Sariani, et al., 2016; Kurniawarti \& Toly, 2014).

H6. Tax justice affects tax evasion

\section{Methodology}

\section{Population and Sample}

The population of this research is MSME's in the Pasar Tanah Abang. The unit of analysis is MSME's of the Block F Pasar Tanah Abang who have Tax ID Number, while the sample is taken by convenience sampling method where from 1,155 MSME's in Pasar Tanah Abang, only a few traders have the time and are willing to fill out the questionnaire. In accordance with the Slovin formula that from a population of 1,155 populations, a sample of this study is 103 people.

\section{Operational Variable}

Developing tax provisions article 38 and article 39 of Law Number 28 Year 2007 concerning General Provisions and Tax Procedures and limitation of the analysis unit at the SMEs in Pasar Tanah Abang that already have a TIN, tax evasion variables as dependent in this study are measured using dimensions and indicators embezzlement on tax payments and embezzlement on tax reporting.

As an independent variable, the measurement of each variable adopts the measurement of variables that have been used in subsequent studies. Adopts Rosianti (2014) with a few modifications, the religiosity in this study was measured using the dimensions of trust and obedience. While ethical variables are measured using the dimensions of honesty and right and wrong as used by Tarmidi \& Waluyo (2014).

Adopts Rosianti (2014) with a few modifications, the understanding of taxation in this study was measured using the dimensions of knowledge and understanding. While information technology services are measured using the ease and usability dimensions that have been used by Ardyaksa (2014) and Paramitha \& Budiasih (2016).

The tax audit in this study was measured using the dimensions of the tax audit procedure and the tax audit process adopted from the Ardyaksa study (2014). While tax justice is measured using the taxation dimensions and tax contributions that have been used by Paramita \& Budiasih (2016).

\section{Hypothesis Testing Method}

Structure Equation Model (SEM) approach used in this study and smart PLS version 3 software used for analyzing the data. Outer loading amount and AVE are used for validity analysis while Composite reliability and Cronbach's alpha are used for reliability analysis. Amount of adjusted r-square and amount of inner and other endogenous variables on exogenous variables and also moderation variables used for hypothesis analysis. 
INTERNATIONAL JOURNAL OF ACADEMIC RESEARCH IN BUSINESS AND SOCIAL SCIENCES

Vol. 10, No. 5, May, 2020, E-ISSN: 2222-6990 ㄷ 2020 HRMARS

\section{Result}

\section{Characteristics Respondent}

Tabel 1. Characteristics Respondent

\begin{tabular}{|c|c|c|c|c|}
\hline Age & $21-30$ yo & $31-40$ yo & $41-50$ yo & $>50$ yo \\
\hline Amount & 40 & 31 & 0 & 4 \\
$\%$ & 0.533 & 0.413 & 0.000 & 0.053 \\
\hline Gender & \multicolumn{2}{|c|}{ Male } & \multicolumn{2}{c|}{ Female } \\
\hline Amount & \multicolumn{2}{|c|}{69} & \multicolumn{2}{c|}{34} \\
\hline$\%$ & \multicolumn{2}{|c|}{0.301} \\
\hline
\end{tabular}

In table 1 it can be explained that the majority of respondents are male with ages between 21-30 years old. This age is a productive age and should be more technological updates than old age so that it might affect the answers of the questionnaire in this study.

\section{Descriptive Analysis}

Tabel 2. Descriptive Analysis

\begin{tabular}{|c|c|c|c|c|}
\hline Variable & Min & Max & Mean & Std. Dev. \\
\hline Y. Tax Evasion & 1 & 4 & 2.1044 & 0.8436 \\
\hline X1. Religiousity & 1 & 4 & 3.5049 & 0.6673 \\
\hline X2. Ethics & 1 & 4 & 3.1869 & 0.6290 \\
\hline $\begin{array}{l}\text { X3. Understanding } \\
\text { X4. Information }\end{array}$ & 1 & 4 & 3.1981 & 0.5326 \\
\hline Technology & 1 & 4 & 2.9393 & 0.6608 \\
\hline X5. Tax Audit & 1 & 4 & 3.1481 & 0.6316 \\
\hline X6. Tax Justice & 1 & 4 & 2.9515 & 0.7333 \\
\hline
\end{tabular}

On the table 2 can be seen that all answers from respondents for each variable is good, with a range score of 1 to 4 explaining that respondent answers vary and with an average of 2 indicates that respondents disagree with statements for each variable, while on average 3 indicates that the respondent agrees with the statement contained in the questionnaire. All standard deviation values are smaller than the average value, this indicates that all data is good. 
INTERNATIONAL JOURNAL OF ACADEMIC RESEARCH IN BUSINESS AND SOCIAL SCIENCES Vol. 10, No. 5, May, 2020, E-ISSN: 2222-6990 @ 2020 HRMARS

Table 3. Goodfit Analysis

\begin{tabular}{ccc}
\hline Variable & AVE & $\begin{array}{c}\text { Composite } \\
\text { Reliability }\end{array}$ \\
\hline TE & 0.660 & 0.885 \\
RE & 0.778 & 0.933 \\
ET & 0.652 & 0.788 \\
UN & 0.600 & 0.854 \\
IT & 0.723 & 0.912 \\
AU & 0.567 & 0.835 \\
JU & 0.594 & 0.724 \\
\hline
\end{tabular}

Note: $\mathrm{TE}=$ Tax Evasion, $\mathrm{RE}=$ Religiousity, $\mathrm{ET}=$ Ethics, $\mathrm{UN}=$ Understanding, IT= Information Technology, $\mathrm{AU}=$ Tax Audit, JU= Tax Justice

Based on the table 3 can be seen that AVE amount of each variable is more than 0.05 and Composite Reliability amount of each variable is more than 0.7 , that mean data is valid and reliable (Ghozali \& Latan, 2015)

\section{Hypothesis Test}

Table 4. Hypotehesis Test

\begin{tabular}{|c|c|c|c|c|c|c|c|c|c|}
\hline \multirow[b]{2}{*}{$\begin{array}{c}\text { Variabl } \\
\mathrm{e}\end{array}$} & \multicolumn{3}{|c|}{ All } & \multicolumn{3}{|c|}{ Internal Factors } & \multicolumn{3}{|c|}{ External Factors } \\
\hline & $\begin{array}{c}\text { Origin } \\
\text { al } \\
\text { Sampl } \\
\text { e } \\
\text { Estim } \\
\text { ate }\end{array}$ & $\begin{array}{l}\text { t- } \\
\text { Stat }\end{array}$ & $\begin{array}{c}\mathrm{t}- \\
\text { tabl } \\
\mathrm{e}\end{array}$ & $\begin{array}{l}\text { Origi } \\
\text { nal } \\
\text { Samp } \\
\text { le } \\
\text { Estim } \\
\text { ate }\end{array}$ & t-Stat & $\begin{array}{c}\text { t- } \\
\text { tabl } \\
\mathrm{e}\end{array}$ & $\begin{array}{c}\text { Origi } \\
\text { nal } \\
\text { Samp } \\
\text { le } \\
\text { Estim } \\
\text { ate }\end{array}$ & $\begin{array}{l}\mathrm{t}- \\
\text { Stat }\end{array}$ & $\begin{array}{c}\mathrm{t}- \\
\text { tabl } \\
\mathrm{e}\end{array}$ \\
\hline RE & $\begin{array}{r}- \\
0.047 \\
\end{array}$ & $\begin{array}{l}0.25 \\
9 \\
\end{array}$ & $\begin{array}{r}1.29 \\
0 \\
\end{array}$ & $\begin{array}{r}- \\
0,122 \\
\end{array}$ & 0,684 & $\begin{array}{r}1.29 \\
0 \\
\end{array}$ & & & \\
\hline ET & $\begin{array}{r}- \\
0.306\end{array}$ & $\begin{array}{l}1.59 \\
6^{*} \\
\end{array}$ & $\begin{array}{r}1.29 \\
0 \\
\end{array}$ & $\begin{array}{r}- \\
0,293 \\
\end{array}$ & $\begin{array}{l}1,635 \\
*\end{array}$ & $\begin{array}{r}1.29 \\
0 \\
\end{array}$ & & & \\
\hline UN & 0.361 & $\begin{array}{l}1.67 \\
5 * * \\
\end{array}$ & $\begin{array}{r}1.66 \\
0 \\
\end{array}$ & 0,379 & $\begin{array}{l}1,753 \\
* *\end{array}$ & $\begin{array}{r}1.66 \\
0\end{array}$ & & & \\
\hline IT & $\begin{array}{r}- \\
0.130 \\
\end{array}$ & $\begin{array}{l}0.67 \\
2 \\
\end{array}$ & $\begin{array}{r}1.29 \\
0 \\
\end{array}$ & & & & $\begin{array}{r}- \\
0.153 \\
\end{array}$ & $\begin{array}{r}0.6 \\
17 \\
\end{array}$ & $\begin{array}{r}1.29 \\
0 \\
\end{array}$ \\
\hline $\mathrm{AU}$ & $\begin{array}{r}- \\
0.070\end{array}$ & $\begin{array}{l}0.35 \\
3 \\
\end{array}$ & $\begin{array}{r}1.29 \\
0 \\
\end{array}$ & & & & $\begin{array}{r}- \\
0.110\end{array}$ & $\begin{array}{r}0.4 \\
68 \\
\end{array}$ & $\begin{array}{r}1.29 \\
0 \\
\end{array}$ \\
\hline $\mathrm{JU}$ & 0.223 & $\begin{array}{l}1.33 \\
2^{*} \\
\end{array}$ & $\begin{array}{r}1.29 \\
0 \\
\end{array}$ & & & & 0.261 & $\begin{array}{r}0.9 \\
90 \\
\end{array}$ & $\begin{array}{r}1.29 \\
0 \\
\end{array}$ \\
\hline $\begin{array}{l}\text { Observ } \\
\text { ation }\end{array}$ & & & 103 & & & 103 & & & 103 \\
\hline $\begin{array}{l}\text { R- } \\
\text { Square }\end{array}$ & & & 0.202 & & & 0.155 & & & 0.082 \\
\hline
\end{tabular}


INTERNATIONAL JOURNAL OF ACADEMIC RESEARCH IN BUSINESS AND SOCIAL SCIENCES Vol. 10, No. 5, May, 2020, E-ISSN: 2222-6990 @ 2020 HRMARS

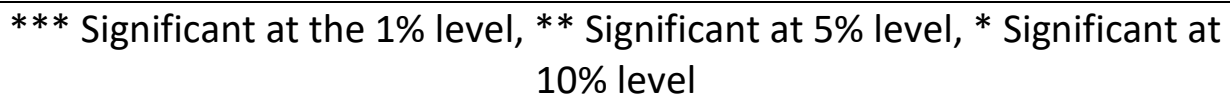

Note: $\mathrm{TE}=$ Tax Evasion, $\mathrm{RE}=$ Religiousity, $\mathrm{ET}=$ Ethics, UN= Understanding, $\mathrm{IT}=$ Information Technology, $\mathrm{AU}=\mathrm{Tax}$ Audit, $\mathrm{JU}=$ Tax Justice

In table 4 it can be seen that the ethical variables, understanding of taxation and tax justice have a significant effect so that hypothesis 2, hypothesis 3 and hypothesis 6 are accepted while others are not. These results explain that ethics have a negative effect on tax evasion so when a taxpayer has good ethics, tax evasion actions will not be done because it violates the principle that the action is wrong. These results are in line with research by Showa \& Utomo (2018) and Surahman \& Putra (2018).

The variable understanding of taxation has a positive influence on tax evasion, meaning that when the taxpayer has expertise in understanding the procedures and provisions of taxation, it will actually encourage him to carry out tax evasion. In the tax justice variable found a positive effect on tax evasion, these results indicate that respondents have not felt fairness in the functions and benefits of tax so far so that thinking that the action of tax evasion is not a problem to do. The results of this study are in line with research by Utami \& Helmi (2016), Ervana (2019), Handayani \& Cahyonowati (2014).

In a comparative test it can be seen that internal factors such as religiosity, ethics and understanding have a stronger influence on taxpayers for tax evasion actions carried out or not compared to external factors such as information technology, tax audit and justice. It can be explained that taxpayers in Indonesia are taxpayers with internal locus of control because they are more able to control themselves than from external influences such as the government in terms of tax evasion actions.

\section{Conclusion}

This study found the following results:

a. Internal factors in this study are known to have a significant effect on tax evasion such as ethics and taxation understanding, but religiosity is not.

b. External factors in this study are known to have a significant effect on tax evasion such as Tax Justice, even though Information Technology and Tax Examination are not.

c. From comparative analysis, it is known that internal factors affect taxpayers more in tax evasion than external factors. This result explains that taxpayers in Indonesia especially traders in Pasar Tanah Abang have more internal locus of control than external locus of control in terms of tax evasion.

\section{Implication and Suggestion}

The results of this study can be used as a reference by the government in minimizing tax evasion actions so that tax revenue continues to increase. Internal factors for taxpayers are more influential for Indonesian taxpayers in tax evasion actions than external factors, so the government can make special plans for taxpayers to increase tax compliance voluntarily and minimize voluntary tax evasion actions. The results of the study can also be input for further research on taxes in Indonesia in order to analyze the personal factors of taxpayers. 
INTERNATIONAL JOURNAL OF ACADEMIC RESEARCH IN BUSINESS AND SOCIAL SCIENCES

Vol. 10, No. 5, May, 2020, E-ISSN: 2222-6990 @ 2020 HRMARS

\section{Acknowledgment}

This study supported by the Faculty of Economic and Business and Research Center of Universitas Mercu Buana and Universitas Bhayangkara Jakarta Raya, We are grateful for the supported from Dean, Rector, Research Center team and especially respondents in this study.

\section{References}

Ardyaksa, T. K., \& Kiswanto. (2014). Pengaruh Keadilan, Tarif Pajak, Ketepatan Pengalokasian, Kecurangan, Teknologi dan Informasi Perpajakan Terhadap Tax Evasion. Accounting Analysis Journal, 3(4), pp. 475-484

Basri, Y. M. (2015). Pengaruh Gender, Religiusitas Dan Sikap Love of Money Pada Persepsi Etika Penggelapan Pajak Mahasiswa Akuntansi. Jurnal IImiah Akuntansi dan Bisnis, 10(1), pp. 45-54

Dewi, N. K. T. J., \& Merkusiwati, N. K. L. A. (2017). Faktor-Faktor yang Mempengaruhi Persepsi Wajib Pajak mengenai Etika atas Penggelapan Pajak (Tax Evasion). E-Jurnal Akuntansi Universitas Udayana, 18(3), pp. 2534-2564

Dharma, L., Agusti, R., \& Kurnia, P. (2016). Pengaruh Gender, Pemahaman Perpajakan dan Religiusitas Terhadap Persepsi Penggelapan Pajak. Jurnal Online Mahasiswa Fakultas Ekonomi, 3(1), pp. 1565-1578

Ervana, O. N. (2019). Pengaruh Pemeriksaan Pajak, Keadilan Pajak Dan Tarif Pajak Terhadap Penggelapan Pajak (Studi Kasus Pada Kantor Pelayanan Pajak Pratama Klaten). Jurnal Akuntansi Pajak Dewantara, 1(1), pp. 80-92, DOI 10.24964/japd.v1i1.802

Fitriyanti, I., Fauzi, A., \& Armeliza, D. (2017). Pengaruh Ketepatan Pengalokasian, Teknologi dan Informasi Perpajakan, dan Diskriminasi Terhadap Penggelapan Pajak (Tax Evasion). Jurnal IImiah Wahana Akuntansi, 12(1), pp. 84-104, doi.org/1021009/wahana 012/1.6

Friskianti, Y., \& Handayani, B. D. (2014). Pengaruh Self Asessment System, Keadilan, Teknologi Perpajakan, dan Ketidakpercayaan Kepada Fiskus Terhadap Tindakan Tax Evasion. Accounting Analysis Journal, 3(4), pp. 543-552

Ghozali, I., \& Latan, H. (2015). Partial Least Square: Konsep, Teknik dan Aplikasi Menggunakan Program SmartPLS 3.0 (Edisi 2). Semarang: Badan Penerbit Universitas Diponegoro

Handayani, A. M., \& Cahyonowati, N. (2014). Analisis Faktor-Faktor yang Mempengaruhi Persepsi Wajib Pajak Mengenai Penggelapan Pajak. Diponegoro Journal of Accounting, 3(3), pp. 1-7

Ihsanuddin. (2016). Panama Papers yang Tak Pernah Mengguncang Indonesia. Download from https://nasional.kompas.com/read/2016/06/17/19584921/panama.papers.yang.tak.pernah. mengguncang.indonesia?page=all

Ismarita, G., Zirman \& Ilham, E. (2018). Pengaruh Keadilan, Tarif Pajak, Teknologi dan Informasi, Diskriminasi, dan Sistem Perpajakan Terhadap Penggelapan Pajak (Studi Kasus Pada WPOP Pedagang Eceran di KPP Pratama Rengat). Jurnal Online Mahasiswa, 1(1), pp. 1-15

Kurniawati, M., \& Toly, A. A. (2014). Analisis Keadilan Pajak, Biaya Kepatuhan, dan Tarif Pajak Terhadap Persepsi Wajib Pajak Mengenai Penggelapan Pajak di Surabaya Barat. Tax and Accounting Review, 4(2), pp. 1-12

Maghfiroh, D., \& Fajarwati, D. (2016). Persepsi Wajib Pajak Mengenai Pengaruh Keadilan, Sistem Perpajakan dan Sanksi Perpajakan Terhadap Penggelapan Pajak. Jurnal Riset Akuntansi \& Komputerisasi Akuntansi, 7(1), pp. 39-55 
INTERNATIONAL JOURNAL OF ACADEMIC RESEARCH IN BUSINESS AND SOCIAL SCIENCES

Vol. 10, No. 5, May, 2020, E-ISSN: 2222-6990 @ 2020 HRMARS

Mira., \& Khalid, A. (2016). Pengaruh Self Assesment System dan Pemeriksaan Pajak Terhadap Tax Evasion Dengan Moralitas Pajak Sebagai Variabel Moderat Pada KPP Pratama Makassar Utara. Jurnal IImiah Akuntansi Peradaban, II(1), pp. 89-107

Nickerson, I., Pleshko, L., \& McGee, R. W. (2009). Presenting the Dimensionality of an Ethics Scale Pertaining to Tax Evasion. Journal of Legal, Ethical and Regulatory Issues, 12(1), pp. 10-14

Paramita, A. A. M. P., \& Budiasih, I. G. A.N. (2016). Pengaruh Sistem Perpajakan, Keadilan, dan Teknologi Perpajakan Pada Persepsi Wajib Pajak mengenai Penggelapan Pajak. E-Jurnal Akuntansi Universitas Udayana, 17(2), 1030-1056

Permatasari, I., \& Laksito, H. (2013). Minimalisasi Tax Evasion Melalui Tarif Pajak, Teknologi dan Informasi Perpajakan, Keadilan Sistem Perpajakan, dan Ketepatan Pengalokasian Pengeluaran Pemerintah (Studi Empiris pada Wajib Pajak Orang Pribadi di Wilayah KPP Pratama Pekanbaru Senapelan). Diponegoro Journal of Accounting, 2(2), pp. 1-10

Putri, H., Tanjung, A. R., \& Azhari, S. (2017). Pengaruh Sistem Perpajakan, Diskriminasi, Kepatuhan dan Pengetahuan Perpajakan Terhadap Persepsi Wajib Pajak Mengenai Etika Penggelapan Pajak (Studi Empiris pada Wajib Pajak Orang Pribadi di Wilayah Kota Pekanbaru). Jurnal Online Mahasiswa Fakultas Ekonomi, 4(1), pp. 2045-2059

Salebu, J. T. (2019). Mengukur Kinerja Penerimaan Pajak 2019. Download from https://www.ssas.co.id/mengukur-kinerja-penerimaan-pajak-2019/

Sariani, P., Wahyuni, M. A., \& Sulindawati, N. L. G. E. (2016). Pengaruh Keadilan, Sistem Perpajakan, Diskriminasi, dan Biaya Kepatuhan Terhadap Persepsi Wajib Pajak Mengenai Etika Penggelapan Pajak (Tax Evasion) pada KPP Pratama Singaraja. E-Journal S1 Ak Universitas Pendidikan Ganesha, 6(3), pp. 1-11

Sarpingah, S., Sormin, F., and Handayani, R. (2017). Influence of Taxation Knowledge and Socialization of Implementation PP. 46 Year 2013 on Tax Compliance for Certain WPOP Small and Medium Business (UMKM) Owner (Case Study in KPP Pratama Cengkareng, West Jakarta). Research Journal of Finance and Accounting, 8(22), pp. 128-136.

Sofha, D., \& Utomo, S. D. (2018). Keterkaitan Religiusitas, Gender, LOM dan Persepsi Etika Penggelapan Pajak. Jurnal IImu Manajemen dan Akuntansi Terapan, 9(2), pp. 43-61

Surahman, W., \& Putra, U.Y. (2018). Faktor-faktor Persepsi Wajib Pajak Terhadap Etika Penggelapan Pajak. Jurnal REKSA: Rekayasa Keuangan, Syariah, dan Audit, 5(1), pp. 1-10

Tarmidi, D., \& Waluyo. (2014). Faktor-Faktor yang Mempengaruhi Kepatuhan Pajak, Dengan Pendekatan Perilaku dan Etika (Studi Empiris Pada Perusahaan PMA Yang Terdaftar Di Kanwil DJP Jakarta Khusus). TEKUN: Jurnal Telaah Akuntansi dan Bisnis, 5(1), pp. 49-68

Tarmidi, D. (2019). Tax Compliance: Impact of Employee Internal Factors, Moderated by Tax Uncertainty. International Journal of Academic Research Business and Social Sciences, 9(5), pp. 294-304

Utama, M. S. (2015). Ditjen Pajak Serahkan Tersangka Kasus Penggelapan Pajak Rp.19,6 Miliar ke Kejaksaan. Siaran Pers Direktorat Jenderal Pajak Kementrian Keuangan

Utami, D., \& Aji, A. W. (2015). Persepsi Wajib Pajak Orang Pribadi tentang Pelaksanaan Self Assessment System Terhadap Tindakan Tax Evasion di Kulon Progo. Jurnal Akuntansi, 3(1), pp. 33-39

Utami, P. D., \& Helmy, H. (2016). Pengaruh Tarif Pajak, Teknologi Informasi Perpajakan, dan Keadilan Sistem Terhadap Penggelapan Pajak: Studi Empiris pada WPOP yang Melakukan Usaha di Kota Padang. Jurnal Wahana Riset Akuntansi, 4(2), pp. 893-904 
INTERNATIONAL JOURNAL OF ACADEMIC RESEARCH IN BUSINESS AND SOCIAL SCIENCES

Vol. 10, No. 5, May, 2020, E-ISSN: 2222-6990 @ 2020 HRMARS

Vionita, C., Ratnawati, V., \& Rusli. (2015). Pengaruh Keadilan Pajak, Kualitas Pelayanan Pajak, Kemungkinan Terdeteksinya Kecurangan, Sanksi Perpajakan, dan Tarif Pajak Terhadap Persepsi Wajib Pajak Mengenai Penggelapan Pajak. Jurnal Online Mahasiswa Fakultas Ekonomi, 2(2), pp. 1-15

Widjaja, P. N. K., Lambey, L., \& Walandouw, S. K. (2017). Pengaruh Diskriminasi dan Pemeriksaan Pajak Terhadap Persepsi Wajib Pajak Orang Pribadi Mengenai Penggelapan Pajak di Kota Bitung (Studi Kasus Pada WPOP yang ditemui di KPP Pratama Bitung). Jurnal Riset Akuntansi Going Concern, 12(2), pp. 541-552

Winarsih, E. (2018). Pengaruh Sistem Perpajakan, Kualitas Pelayanan dan Terdeteksinya Kecurangan Terhadap Penggelapan Pajak. Atestasi Jurnal Ilmiah Akuntansi, 1(1), pp. 55-69

Zirman. (2015). Pengaruh Penegakan Hukum dan Gender Terhadap Penggelapan Pajak Dimediasi oleh Moral Pajak. Akuntabilitas, VIII(2), pp. 133-147 